\title{
Health beliefs and adherence of the elderly to fall prevention measures: a quasi-experimental study
}

\author{
Crenças em saúde e adesão de idosos às medidas preventivas de quedas: estudo quase experimental
}

Creencias en salud y adhesión de ancianos a las medidas preventivas de caídas: estudio cuasi experimental

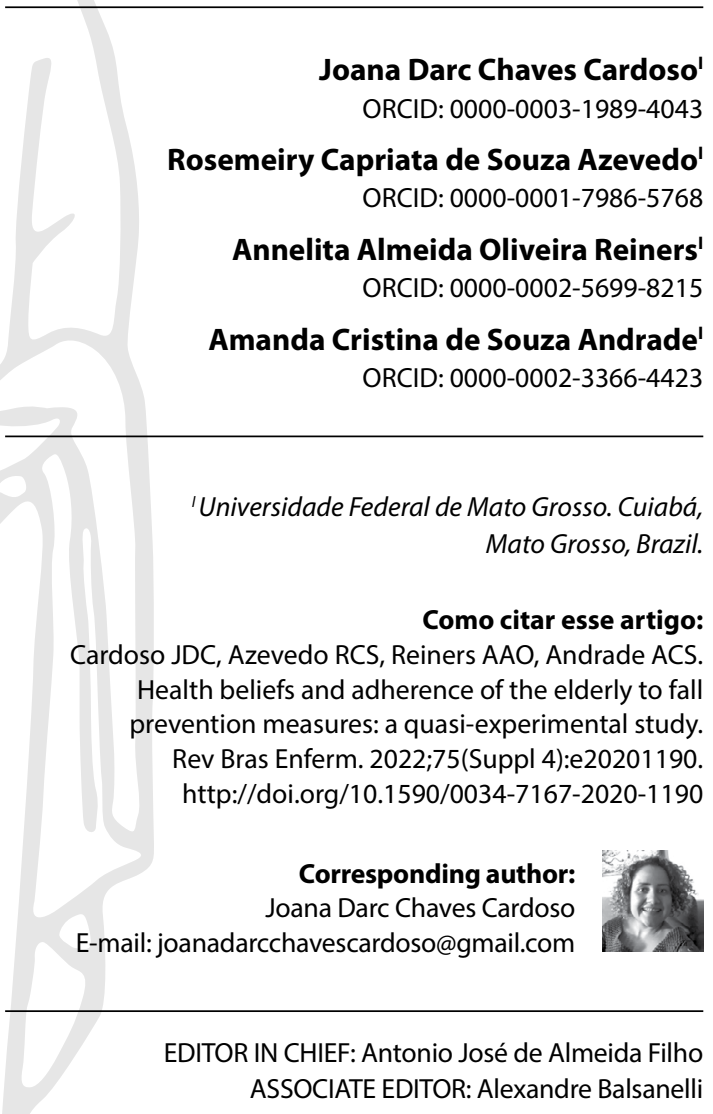

Submission: 11-17-2020

Approval: 07-05-2021

\section{ABSTRACT}

Objective: To evaluate the effect of an educational intervention on health beliefs and adherence of elderly people to fall prevention measures. Methods: This is a quasi-experimental study, carried out at the Senior Citizens' Center. Sixty-eight elderly completed the intervention. The intervention consisted of four meetings focused on beliefs about falls and prevention, and the evaluation occurred at baseline and 30 days after completion. Results: The elderly were predominantly women $(83.82 \%)$, with one to four years of schooling $(36.76 \%)$, with health problems $(95.59 \%)$, and $48.53 \%$ had fallen. There was a significant increase in perceived susceptibility, severity, benefits, barriers, and total health belief score post educational intervention. By adding total to partial adherence, there was a significant increase in the adherence of the elderly to fall prevention measures after the educational intervention. Conclusion: Educational intervention was able to improve the beliefs and adherence of the elderly to fall prevention measures.

Descriptors: Elderly; Accidental Falls; Health Education; Accident Prevention; Treatment Adherence and Compliance.

\section{RESUMO}

Objetivo: Avaliar o efeito de uma intervenção educativa nas crenças em saúde e na adesão de idosos às medidas preventivas de quedas. Métodos: Estudo quase experimental, realizado em Centro de Convivência para Idosos. Concluíram a intervenção 68 idosos. A intervenção consistiu em quatro encontros com foco nas crenças sobre quedas e prevenção, e a avaliação ocorreu na baseline e 30 dias após o término. Resultados: Predominaram entre os idosos: mulheres $(83,82 \%)$, um a quatro anos de estudo $(36,76 \%)$, com problemas de saúde $(95,59 \%)$; e $48,53 \%$ tiveram queda. Houve aumento significante na percepção de suscetibilidade, da severidade, dos benefícios, das barreiras e no escore total de crenças em saúde pósintervenção educativa. Ao somar a adesão total à parcial, houve aumento significante da adesão dos idosos às medidas preventivas de quedas pós-intervenção educativa. Conclusão: Intervenção educativa foi capaz de melhorar as crenças e a adesão dos idosos às medidas preventivas de quedas.

Descritores: Idoso; Acidentes por Quedas; Educação em Saúde; Prevenção de Acidentes; Cooperação e Adesão ao Tratamento.

\section{RESUMEN}

Objetivo: Evaluar efecto de una intervención educativa en las creencias en salud y adhesión de ancianos a medidas preventivas de caídas. Métodos: Estudio cuasi experimental, realizado en Centro de Convivencia para Ancianos. Concluyeron la intervención 68 ancianos. La intervención consistió en cuatro encuentros con enfoque en creencias sobre caídas y prevención, y la evaluación ocurrió en la baseline y 30 días tras el término. Resultados: Predominaron entre los ancianos: mujeres $(83,82 \%)$, un a cuatro años de estudio $(36,76 \%)$, con problemas de salud $(95,59 \%) ;$ y $48,53 \%$ tuvieron caída. Hubo aumento significativo en la percepción de susceptibilidad, de severidad, de beneficios, de barreras y escore total de creencias en salud postintervención educativa. Al sumar la adhesión total a parcial, hubo aumento significativo de adhesión de ancianos a medidas preventivas de caídas postintervención educativa. Conclusión: Intervención educativa fue capaz de mejorar las creencias y la adhesión de ancianos a medidas preventivas de caídas.

Descriptores: Anciano; Accidentes por Caídas; Educación en Salud; Prevención de Accidentes; Cumplimiento y Adherencia al Tratamiento. 


\section{INTRODUCTION}

Falls are a major threat to the health and independence of the elderly. Most of them happen at home due to factors that can be modified $^{(1-2)}$. The literature presents several possibilities for the prevention of this grievance ${ }^{(3)}$. However, despite the advances in research on preventive measures (PM) for falls, studies show that the non-adherence or low adherence of the elderly to these measures is still a problem ${ }^{(3-6)}$.

Several factors can influence the adherence of the elderly to fall PM, among them: compromised health conditions, previous unpleasant experiences, inability to go to the intervention site, lack of time, support from professionals or family, and knowledge about the benefits of the activities ${ }^{(7-10)}$.

Another factor that may influence the adherence behavior of the elderly to falls PMs is their beliefs. As reported in studies, the elderly believe that falls are natural and inevitable events of old age and therefore there is no way to prevent them or that they occur by divine will(11-12). Others believe that falls happen only to older, frail elderly people; that they are more frequent during physical activities; that they pose a serious threat to health; and that restricting their activities can help prevent the event ${ }^{(11,13)}$.

Given the magnitude of the problem of falls, there is a recommendation that more interventions be conducted to improve the adherence behavior of the elderly to the $P M s^{(14-16)}$ and decrease the influence of risk factors, such as beliefs ${ }^{(5,17)}$. Studies have shown that educational interventions can be effective in modifying health beliefs and behaviors ${ }^{(18-21)}$. In these interventions, health education is a low-cost technique that brings positive results for people's health ${ }^{(22)}$. Furthermore, it is an opportunity to re-educate the elderly about fall prevention behaviors, allowing them to improve their adherence to the $\mathrm{PMs}^{(14,23)}$.

Theory-based interventions are more effective for research on prevention behaviors ${ }^{(24-25)}$, especially in the adherence to the fall PMs ${ }^{(15)}$. Those that use theories from the behavioral sciences are the most appropriate ${ }^{(24-25)}$, especially that of the Health Belief Model (HBM) ${ }^{(15)}$.

In the literature, only two studies were found, that investigated health beliefs and adherence to fall prevention in the elderly, evaluating the effect of educational interventions on health beliefs and behaviors. Both observed improvement in beliefs and adherence after the intervention ${ }^{(5,26)}$.

Thus, the literature has shown that elderly people's beliefs about falls and their prevention can influence the adoption of preventive behaviors; that they can be configured as barriers to the adoption of fall prevention strategies; and that interventions can be effective in improving the adherence of the elderly to fall prevention $\mathrm{PMs}^{(5,27)}$. Considering these factors, it can be seen that this study helps in the search for effective strategies to modify erroneous beliefs about falls and to favor preventive behaviors.

\section{OBJECTIVE}

To evaluate the effect of an educational intervention on health beliefs and adherence of elderly to fall prevention measures.

\section{METHODS}

\section{Ethical aspects}

This study was approved by the Research Ethics Committee and by the Brazilian Registry of Clinical Trials (RBR-8gd5g8).

\section{Study design, location and time period}

This is a quasi-experimental study, with time-series design, carried out at a Senior Citizens Center (SCC) in Cuiabá, state of Mato Grosso (MT), in the period from June to October 2019. This center offers the elderly physical (water aerobics, hydrotherapy, gymnastics, and weight-training), manual (crafts, sewing), educational (Youth and Adult Education), and cultural (theater, dancing, and outings) activities from Monday to Friday in the morning and afternoon. The elderly enroll annually in the activity/ies they intend to participate in.

\section{Population and sample}

The study population was composed of all the elderly participating in the SCC. At the time, approximately 418 elderly people were enrolled in physical, manual, educational (Youth and Adult Education), and cultural activities.

The sample was estimated considering 95\% confidence (type I error $=5 \%$ ), type II error of $20 \%$, i.e., power of $80 \%$, proportion of adherence to the falls PMs of $64.36 \%$ (measured in the pilot test), minimum difference before and after the educational intervention of $4 \%$, which totaled 66 elderly. To reduce possible losses, 30\% were added to the calculated sample, totaling 97 elderly individuals.

The study included people aged 60 years or older, who performed at least one of the physical activities and had a $75 \%$ attendance rate at the educational meetings. Elderly people who had cognitive and mental difficulties measured by the Mini Mental State Examination (MMSE) were excluded. The cut-off points used were: 13, for illiterate elderly people; 18 , for those with up to eight years of schooling; and 26 , for the elderly with more than eight years of schooling ${ }^{(28)}$.

In all, 109 elderly people were recruited (baseline), of whom 68 completed the intervention protocol.

\section{Study protocol}

The protocol of the educational intervention was built based on the HBM and considered the personal, socioeconomic, and cultural characteristics of the participants. It is a theoretical model widely used to explain health behaviors ${ }^{(29)}$ and plan behavioral interventions ${ }^{(24)}$.

The HBM was developed in the 1950s by Becker, Drachman, Kirsch and Rosenstock, social psychologists from the United States Public Health Service, seeking to establish relationships between individual behaviors and beliefs to explain people's adoption of prevention behaviors ${ }^{(30-31)}$. It is composed of four dimensions: (1) perceived susceptibility $\nabla$ refers to the perceived susceptibility to having a problem or illness; (2) perceived severity $\nabla$ refers to the person's perception of the severity and/or consequences that the problem or illness may entail; (3) perceived benefits to taking 
action $\nabla$ refers to the person's perception or understanding of the benefits of actions to minimize the threat of the problem or illness; and (4) perceived barriers to taking action $\bigotimes$ refers to the perception about the negative aspects that hinder or prevent the adoption of the suggested behavior ${ }^{(30,32-33)}$.

The intervention occurred in six times (T0 to T5), with four meetings of educational activities (T1 to T4). At recruitment and pre-intervention (T0), the elderly were contacted and recruited by the researcher at the SCC during the performance of their activities for presentation of the research objectives, purpose, duration of the intervention, general procedures, and expected results. After this presentation, the elderly were invited to participate in the research; and, for those who accepted, the Free and Informed Consent Term (FICT) was read and signed. Eight possible groups were available for choice, with pre-established days and times according to the activities at the SCC. Subsequently, in the pre-intervention, the screening instrument (MMSE) was applied through an interview; and, to those who reached the established cutoff points, the instruments of sociodemographic characteristics and health conditions, assessment of health beliefs and adherence of the elderly to the falls PMs were applied.

In order that the instruments on health beliefs and adherence to falls PMs could actually measure these events and translate these variables, the content validation of these tools was performed by specialists in the area of geriatrics and gerontology, using the Content Validity Index (CVI). The overall CVI obtained for the Health Beliefs Scale was 0.96 and for the PM of falls questionnaire, 0.99 , indicating its applicability.

The Health Beliefs Scale had 38 statements, of Likert type, ranging from "strongly disagree" (1 point) to "strongly agree" (5 points), distributed among the four dimensions of the HBM (perceived susceptibility, perceived severity, perceived benefits of adhering to fall PMs and perceived barriers to adhering to fall PMs). The total score ranged from 38 to 190 and was obtained by adding the values for each dimension of beliefs and the total score. The interpretation of the total score of beliefs was performed as follows: the higher the score, the higher the perception of susceptibility, of severity to falls, of benefits in adopting fall PMs and the lower the perception of barriers in adopting fall PMs.

The adherence of the elderly to the PMs for falls was verified using a questionnaire with 22 questions about behavioral and environmental preventive measures for falls. The variable "adherence" was obtained through the sum of the points obtained in each answer of the elderly (ranging from 1 to 22). When the elderly answered that they correctly performed the PM questioned, it was considered total adherence. When the elderly answered that sometimes he/she performed the PM correctly, it was considered partial adherence. Two variables were obtained with the sum of the answers of all the elderly: total adherence and partial adherence. For the analyses, we chose to create a third variable, which corresponds to the sum of total adherence plus partial adherence, for considering that the elderly who sometimes correctly performed the PM (partial adherence) also adhered, to some extent, to fall prevention.

Each elderly received a personalized invitation, with information about the dates and times of the meetings and the importance of their participation before the beginning of the educational meetings. The day before each meeting, the researcher sent the elderly reminders of the meeting via WhatsApp, Short Message Service (SMS) and phone calls.

The meetings were conducted by the researcher and a previously trained team, with 90 minutes duration and seven days interval between them. The first meeting (T1) aimed to discuss the perception of susceptibility to falls of the elderly. Two activities were carried out: one, called "puzzle dynamics" and the other, "fall susceptibility"(34), in which the elderly were distributed into small groups and given several printed vignettes in the form of a puzzle ${ }^{(35)}$ with images of elderly people in situations of risk of falling. Then, the groups were asked to assemble the puzzles and discuss the questions: "(a) In this image, is there any situation of risk for the elderly to fall? (b) Do you consider that you might fall in this situation? Justify your answer." Following this, the seniors shared their perception of susceptibility to falls. At the end, the researcher highlighted the misconceptions in the perception of risk factors and brought scientific information about risk factors for falls.

The other activity was the "agree and disagree" dynamic. Initially, two plates were handed out: a red one, for them to raise when they disagreed, and a green one, for when they agreed with the sentences projected and read by the researcher, with mistaken beliefs about falls in the elderly. At the end, the mistaken beliefs were clarified, and scientific information was presented in a language appropriate to the characteristics of the elderly.

The second meeting (T2) aimed to discuss the perception of severity of falls, having as a theme its consequences and complications. To this end, the following activities were developed: (1) "This reminds me" dynamic ${ }^{(34)}$, adapted to stimulate the elderly to reflect on the occurrence of falls, its consequences and complications; (2) images of elderly people with post-fall consequences and complications were distributed for them to observe and identify if they were related to falls; (3) simulation of functional dependence in which the elderly were divided into pairs and took turns in the role of caregiver and dependent elderly person. The simulation included: helping with transportation and moving with a wheelchair; handling a cup with liquid, with the dominant limb immobilized; and walking using a walker. At the end of each activity, a discussion was held to share their experiences and perceptions of the severity of falls.

In the third meeting (T3), the goal was to discuss the PMs of falls and the benefits of adopting them. To do so, the elderly were questioned about why it is necessary to prevent falls. Several objects and printed images were placed in the center of the room with risk factors for falls and PMs for falls (non-slip floor, chair with arm, support bars, elderly people practicing physical exercises). Then, they were asked to divide themselves into groups, look at the objects and images, and discuss which of them prevent falls. Each group selected the objects and images and presented them to the others. The appropriate choices were valued by the researcher, and evidence on PMs of falls available in the literature was brought. At the end of the meeting, the elderly were asked to observe their behaviors and homes during the week to identify necessary and possible adaptations to prevent falls. 
The last meeting (T4) aimed to discuss the perception of barriers to adopt PMs to prevent falls. The elderly presented the possibilities of possible adaptations to be adopted at home and in their behavior to prevent falls. Then, they were asked which barriers they encountered in their daily lives; and ways to overcome them were discussed.

In the post-intervention (T5), which took place 30 days after the end of the educational meetings, the Health Beliefs Scale and the questionnaire on adherence to falls PMs were applied again.

\section{Analysis of results and statistics}

Data analysis was performed using the STATA software, version 12.0. For categorical variables, absolute and relative frequencies were calculated; for continuous variables, mean, with $95 \%$ confidence interval, median, minimum and maximum value, interquartile range, and standard deviation were calculated. The variables "health beliefs" and "adherence of the elderly" presented different scale measures. Therefore, to facilitate comparison between them, their values were transformed into a scale from 0 to 100.

The normality of the data distribution was tested using the Shapiro-Wilk test. The analysis of differences between the measures of health beliefs was obtained using the paired t-test. To verify the effect of the intervention on the adherence of the elderly, the Wilcoxon test for paired samples was used. In all analyses, a $5 \%$ significance level was considered.

\section{RESULTS}

Of the 68 elderly analyzed, most were women (83.82\%), mean age of 70.06 years (SD $=5.92)$, aged 60 to 69 years $(48.53 \%)$, married or in a stable union and widowed (36.76\%), had one to four years of schooling, lived with someone (77.94\%), had family income of one to two minimum wages (42.65\%) and reported a health problem (95.59\%), with a mean of 3.05 morbidities (SD = 1.48) (Table 1).

The main health problems mentioned were osteoarticular and rheumatic, as well as cardiovascular. The regular use of medication was pointed out by $88.24 \%$ of the interviewees, a mean of $2.77(S D=1.39)$. Falls were reported by $48.53 \%$ of the elderly, with a mean of $1.67(\mathrm{SD}=0.78)$, and more than half of the elderly (54.41\%) had never received guidance on falls and prevention (Table 1).

When comparing the effect of the educational intervention on health beliefs pre-intervention and post-intervention, a statistically significant increase was identified in the mean scores of the constructs "perceived susceptibility", "perceived severity", "perceived benefits" and in the total score of beliefs. The total belief score showed a statistically significant increase after the intervention, indicating a lower perception of barriers to adopting fall PMs (Table 2).

There was a significant increase in the indicators of total adherence and decrease in partial adherence $(p<0.0001)$. When the results of total adherence and partial adherence were added, we observed a significant increase in the adherence of the elderly to the PMs after the intervention (Table 3).
Table 1 - Distribution of the elderly according to sociodemographic variables and health conditions, Cuiabá, Mato Grosso, Brazil, 2019

\begin{tabular}{|c|c|c|}
\hline Variable & $\mathbf{n}$ & $\%$ \\
\hline \multicolumn{3}{|l|}{ Sex } \\
\hline Female & 57 & 83.82 \\
\hline Male & 11 & 16.18 \\
\hline \multicolumn{3}{|l|}{ Age group } \\
\hline 60 to 69 years & 33 & 48.53 \\
\hline 70 to 79 years & 29 & 42.65 \\
\hline 80 years or more & 6 & 08.82 \\
\hline \multicolumn{3}{|l|}{ Marital status } \\
\hline Married or in a stable union & 25 & 36.76 \\
\hline Widow/er & 25 & 36.76 \\
\hline Single/divorced/separated & 18 & 26.47 \\
\hline \multicolumn{3}{|l|}{ Years of education (years) } \\
\hline 0 (illiterate) & 10 & 14.71 \\
\hline 1 to 4 & 25 & 36.76 \\
\hline 5 to 8 & 15 & 22.06 \\
\hline$\geq 9$ & 18 & 26.47 \\
\hline \multicolumn{3}{|l|}{ Monthly family income (minimum wages) } \\
\hline$<1$ & 3 & 4.41 \\
\hline 1 to 2 & 29 & 42.65 \\
\hline 2 to 3 & 20 & 29.41 \\
\hline 3 or more & 16 & 23.53 \\
\hline \multicolumn{3}{|l|}{ Health problems } \\
\hline Yes & 65 & 95.59 \\
\hline No & 3 & 4.41 \\
\hline \multicolumn{3}{|l|}{ Main self-reported health problems } \\
\hline Osteoarticular and rheumatic problems & 71 & 35.50 \\
\hline Cardiovascular problems & 68 & 34.00 \\
\hline Endocrine, metabolic and nutritional problems & 27 & 13.50 \\
\hline Neurological problems & 17 & 8.50 \\
\hline $\begin{array}{l}\text { Other problems (gastrointestinal, respiratory, } \\
\text { kidney cyst, urinary infection, enlarged prostate, } \\
\text { leprosy, Chagas' disease) }\end{array}$ & 11 & 5.50 \\
\hline $\begin{array}{l}\text { Psychiatric problems (depression, insomnia, } \\
\text { anxiety) }\end{array}$ & 6 & 3.00 \\
\hline \multicolumn{3}{|l|}{ Regular use of medication } \\
\hline Yes & 60 & 88.24 \\
\hline No & 8 & 11.76 \\
\hline \multicolumn{3}{|l|}{ Fall(s) in the last 12 months } \\
\hline No & 35 & 51.47 \\
\hline Yes & 33 & 48.53 \\
\hline \multicolumn{3}{|l|}{ Guidance about falls } \\
\hline No & 37 & 54.41 \\
\hline Yes & 31 & 45.59 \\
\hline
\end{tabular}

\section{DISCUSSION}

As only two studies have investigated the effect of educational interventions on health beliefs and fall prevention behaviors of the elderly ${ }^{(5,26)}$, the present work is relevant. This is because it is the first HBM-based educational intervention tested in physically active elderly that combined different group strategies to improve both elderly beliefs about falls and fall prevention and adherence to preventive behaviors. Its results reinforce the evidence on the effectiveness of the educational intervention as the only intervention capable of helping professionals who care for the elderly to develop effective actions to improve beliefs and adherence to fall PM. 
Table 2 - Comparison of health beliefs pre-intervention and post-intervention educational, Cuiabá, Mato Grosso, Brazil, 2019

\begin{tabular}{|c|c|c|c|c|c|c|c|}
\hline \multirow{2}{*}{ Variables } & \multicolumn{3}{|c|}{ Pre-intervention $\left(\mathrm{T}_{0}\right)$} & \multicolumn{3}{|c|}{ Post-intervention $\left(\mathrm{T}_{5}\right)$} & \multirow{2}{*}{$\underset{\text { valuel| }}{p}$} \\
\hline & Mean \% (SD*) & Median (ID') & Min..; Máx. ${ }^{5}$ & Mean \% (SD*) & Median (ID') & Min. ; Máx. ${ }^{5}$ & \\
\hline \multicolumn{8}{|l|}{ Health Beliefs } \\
\hline $\begin{array}{l}\text { Dimension } 1 \text { - Perception of } \\
\text { susceptibility to falls }\end{array}$ & $88.14(11.41)$ & $90.00(13.33)$ & $40.00 ; 100.00$ & $95.98(5.04)$ & $98.33(6.67)$ & $83.33 ; 100.00$ & $<0.0001$ \\
\hline $\begin{array}{l}\text { Dimension } 2 \text { - Perception of } \\
\text { severity of falls }\end{array}$ & $96.39(7.20)$ & $100.00(5.71)$ & $65.71 ; 100.00$ & $99.03(2.35)$ & $100.00(0.00)$ & $85.71 ; 100.00$ & 0.0019 \\
\hline $\begin{array}{l}\text { Dimension } 3 \text { - Perception of benefits } \\
\text { in adhering to the RMs for falls }\end{array}$ & $96.61(4.52)$ & $98.67(5.33)$ & $78.67 ; 100.00$ & $98.98(1.79)$ & $100(1.33)$ & $90.67 ; 100.00$ & $<0.0001$ \\
\hline $\begin{array}{l}\text { Dimension } 4 \text { - Perception of barriers } \\
\text { to adhere to fall PMs }\end{array}$ & $60.71(15.44)$ & $61.00(17.00)$ & $20.00 ; 92.00$ & $84.65(9.50)$ & $84.00(14.00)$ & $56.00 ; 98.00$ & $<0.0001$ \\
\hline Total score of beliefs & $85.78(5.26)$ & $86.84(6.32)$ & $69.47 ; 97.89$ & $94.74(2.87)$ & $95.00(3.95)$ & $88.42 ; 99.47$ & $<0.0001$ \\
\hline
\end{tabular}

Table 3 - Comparison of elderly adherence to fall prevention measures pre-intervention and post-intervention education, Cuiabá, Mato Grosso, Brazil, 2019

\begin{tabular}{|c|c|c|c|c|c|c|c|}
\hline \multirow{2}{*}{ Variables } & \multicolumn{3}{|c|}{ Pre-intervention $\left(\mathrm{T}_{0}\right)$} & \multicolumn{3}{|c|}{ Post-intervention $\left(\mathbf{T}_{5}\right)$} & \multirow{2}{*}{$\underset{\text { value }}{\boldsymbol{p}}$} \\
\hline & Mean \% (SD*) & Median (ID ${ }^{\dagger}$ ) & Min.; ; Máx. ${ }^{\S}$ & Mean \% (SD*) & Median (ID') & Min..$^{\ddagger}$ Máx. ${ }^{\S}$ & \\
\hline \multicolumn{8}{|l|}{ Adherence to PMs" of falls } \\
\hline Full adherence & $63.70(11.47)$ & $63.64(18.18)$ & $36.36 ; 86.36$ & $76.67(8.45)$ & $77.27(13.64)$ & $59.09 ; 90.91$ & $<0.0001$ \\
\hline Partial adherence & $9.09(6.76)$ & $9.09(9.09)$ & $0.00 ; 27.27$ & $3.01(3.30)$ & $4.55(4.55)$ & $0.00 ; 13.64$ & $<0.0001$ \\
\hline Full adherence + partial adherence & $72.79(9.34)$ & $72.73(9.09)$ & $50.00 ; 90.91$ & $79.68(7.91)$ & $81.82(13.64)$ & $63.64 ; 90.91$ & $<0.0001$ \\
\hline
\end{tabular}

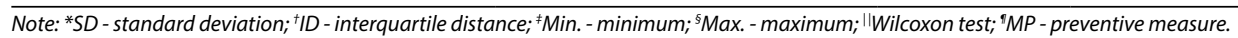

Two important results were found in this research. First, the HBM-supported educational intervention was effective in improving elderly health beliefs about falls and their prevention. This suggests that an educational intervention can have a positive effect on health beliefs. The significant increase in the mean scores of the constructs of health beliefs of the elderly was a similar result to that of other studies using the HBM, although with different themes ${ }^{(20-21,36-37)}$.

Such results may have some explanations. In this study, the intervention considered the close relationship between people's beliefs and their behaviors adopted in an attempt to minimize risk factors or prevent falls. Thus, it was systematically planned based on the four constructs of the HBM seen as influencing factors of health behaviors ${ }^{(20-22,30)}$.

The increase in mean scores of perceived susceptibility after the educational intervention is consistent with other educational interventions based on the HBM in different themes ${ }^{(19-21)}$. This may be related to the fact that, in the intervention, specific strategies were used to work on the perception of the elderly about risk factors in practical situations of their daily lives. It is believed that there was a contribution in the improvement of the perception of the elderly about their susceptibility to falls, as well as in the identification of risk factors for its occurrence at home, in the places they frequent, and in their behavior.

The perception of severity is another construct that can influence the adoption of health behaviors. It was important for the elderly, in improving their perception of the severity of falls, to work on the consequences and complications of falls for their life, health and family, such as injuries, functional dependence, hospitalization, institutionalization, increased costs and death.
In the incidence of preventive behaviors, the perception of barriers is considered an important dimension to predict adherence to PMs. Barriers are considered the negative aspects of the health action recommended to prevent falls, and may prevent the elderly from adopting the PMs. The results of this study can be attributed to the fact that the educational intervention increased the knowledge of the elderly, helping them to perceive the barriers they face in preventing falls and to think of ways to overcome them ${ }^{(19)}$.

As in this investigation, other studies show that the educational intervention based on the HBM is capable of increasing the perception of benefits and improving the adoption of preventive behaviors ${ }^{(20-21)}$. It seems likely that the results obtained here can be attributed to the strategies used, such as the observation and selection of images and objects that the elderly thought prevented falls, making them reflect on the importance of adopting fall prevention PMs in their daily lives. In addition, the fact that the elderly observed their home and behavior and thought about prevention possibilities based on their reality may have triggered an improvement in the perception of the benefits of adopting fall prevention PMs.

The use of theoretical reference in intervention allows the researcher to understand the investigated health behavior, to direct the planning of actions, to identify effective techniques for health behavior change, and to develop evidence-based practices ${ }^{(15,24-25)}$. When guided by a theory, the researcher has the premises to structure the intervention according to the variables that may influence the studied phenomenon ${ }^{(15)}$, which, in the case of the HBM, are susceptibility, severity, barriers and perceived benefits, underpinning the methodological decisions ${ }^{(38)}$. 
Another explanation can be attributed to the planning and execution of the intervention according to the personal, socioeconomic, and cultural characteristics of the participants. Prior to the intervention, there was a concern to obtain knowledge about the sociodemographic and health profile of the elderly, their health beliefs, and their fall prevention behaviors. Knowing the peculiarities of the participants allows the researcher to design the most appropriate actions and strategies for them, ensuring greater effectiveness of the educational activity ${ }^{(38)}$. This allowed the intervention actions to be adapted to the specificities of the elderly, mainly to their level of education, housing conditions, income, beliefs and behaviors in health, mistaken or not.

Finally, another possible reason concerns the techniques and resources applied in the stages of the intervention, such as group dynamics, vignettes, images, objects, and simulation. For a larger group of participants, group dynamics are effective for educational activities carried out in a short period of time ${ }^{(39)}$. It is considered a strategy that favors learning, sharing of concerns, clarification of doubts, and search for solutions to deal with the barriers encountered in the adoption of healthy behaviors ${ }^{(40)}$. Furthermore, it makes it possible to reflect on the beliefs that people have, constituting itself as a facilitator for the awareness of elements present in daily life $\mathrm{e}^{(38,41)}$.

Didactic resources empower the educator's activities, favoring the participant's learning about the theme, their motivation, as well as their active participation in the meetings ${ }^{(38,42)}$. In the intervention, several resources were used for the elderly to think about the severity of falls, such as images of the elderly with their consequences and complications.

The vignette technique is effective in simulating a real-life experience and prompting participants to express their attitudes, perceptions, feelings, beliefs, behaviors, and decisions ${ }^{(43-45)}$. In addition, vignettes tend to attract more attention from the participants and facilitate the understanding of the situations to be worked on ${ }^{(43,46)}$. In this study, vignettes with situations of risk of falls experienced in the daily life of the elderly helped them to improve their perception of how susceptible they are to falls, as well as to identify more risk factors for its occurrence at home, in the environments they frequent and in their behavior. This is important, because believing that one is susceptible to a problem or illness is one of the most powerful factors in predicting preventive behavior ${ }^{(19,47)}$.

The simulation technique, on the other hand, provides the establishment of a real environment for the participants ${ }^{(48)}$ for the purpose of practicing, learning, or understanding situations ${ }^{(49)}$. In this study, the simulation of post-fall functional dependence allowed the elderly to experience the need for a caregiver to perform basic activities and to reflect on the practical consequences of falls for their lives and their families.

O second important result of this study is that the educational intervention supported by the HBM was effective in improving the adherence of the elderly to the falls PMs. To our knowledge, other research with this methodological design has not been previously documented, a fact that makes it difficult to compare results. However, other research has observed improved adherence to health behaviors following an educational intervention ${ }^{(21-22,50)}$.

A probable explanation for the improvement in the adherence of the elderly in this study to the PMs may be the use of the strategies and resources of the educational intervention. In addition, we should add that, along with the knowledge offered about falls and its prevention to the elderly in the educational meetings, the PMs of falls worked in this intervention were of situations common to their daily lives, practical, palpable, and possible to be incorporated into their daily lives. One strategy used was to ask each elderly person to observe his/her home and behavior, reflecting on the possibility of modifying both of them to prevent falls. Interventions focused on gradual changes, flexible and simple to be applied in daily life tend to enable greater adherence, since the lower the complexity, the greater the adherence to the recommendations ${ }^{(51)}$. Also, a previous study showed that a fall prevention program developed with handson activities in educational meetings makes more sense to the elderly and favors their adherence behavior ${ }^{(14)}$.

Another probable reason for the improvement in adherence is the fact that each elderly received, the day before each educational meeting, phone calls and messages reinforcing the importance of their participation in the meetings. This may have strengthened their decision to adhere to the falls PMs. One of the aspects that predispose people to accept prevention recommendations are the stimuli they receive, because they make them feel willing to take action to avoid a problem ${ }^{(30,32)}$.

Although this study does not allow us to infer that improved health beliefs of the elderly are related to improved adherence to $P M$, it is reasonable to assume that working on beliefs during the educational intervention contributed to this positive outcome, since the influence of beliefs on the adoption of health behaviors is well established in the literature ${ }^{(5,13)}$. In view of this, it is likely that the elderly who reported adhering to fall prevention actions may have realized how susceptible they are to falls and their consequences, that there are greater benefits than barriers in adhering to fall PMs, resulting in improved adoption of the preventive behavior. The greater the perceived benefits of the health action and the lower the perceived barriers to its adoption, the greater the chances that the person will adopt a preventive behavior ${ }^{(30)}$.

\section{Study limitations}

This study has some limitations. The recruitment of the sample by convenience may reduce the ability of the results to be generalized. There was an attempt to ensure the engagement of all the elderly people enrolled in the SCC in the research, however, several of them did not attend the activities in the established recruitment period. The absence of a control group precluded comparison with the elderly who did not receive the intervention.

\section{Contributions to Nursing, Health, or Public Policy}

The findings of this study contribute to the advancement of knowledge in the areas of health and nursing, since they show that the implementation of an educational intervention can help the elderly in the adoption of preventive behaviors. This brings the possibility of it being applied at all levels of health care to promote comprehensive care, quality of life and autonomy of the elderly. 


\section{CONCLUSION}

The hypothesis that a HBM-based educational intervention would improve elderly health beliefs and adherence to falls PMs was confirmed. These results support health education as a unique intervention that has the ability to improve health beliefs and the adoption of fall prevention behaviors. It is recommended that more intervention studies based on benchmarks such as the
HBM be conducted. In particular, randomized clinical trials are suggested to investigate whether modifying the health beliefs of the elderly would lead to improved adherence to falls PM.

\section{FUNDING}

The research was funded by the National Program for Academic Cooperation (Procad), edict number 071/2013.

\section{REFERENCES}

1. Elias Filho J, Borel WP, Diz JBM, Barbosa AWC, Britto RR, Felício DC. Prevalence of falls and associated factors in community-dwelling older Brazilians: a systematic review and meta-analysis. Cad Saude Publica. 2019;35(8). https://doi.org/10.1590/0102-311X00115718

2. Abreu DROM, Novaes ES, Oliveira RR, Mathias TAF, Marcon SS. Fall-related admission and mortality in older adults in Brazil: trend analysis. Ciênc Saúde coletiva. 2018;23(4):1131-1141. https://doi.org/10.1590/1413-81232018234.09962016

3. Mikolaizak AS, Lord SR, Tiedemann A, Simpson P, Caplan G, Bendall JC, et al. Adherence to a multifactorial fall prevention program following paramedic care: Predictors and impact on falls and health service use: results from an RCT a priori subgroup analysis. Australas J Ageing. 2018;37(1):54-61. https://doi.org/10.1111/ajag.12465

4. Hager AGM, Mathieu N, Lenoble-Hoskovec C, Swanenburg J, Bie R, Hilfiker R. Effects of three home-based exercise programmes regarding falls, quality of life and exercise-adherence in older adults at risk of falling: protocol for a randomized controlled trial. BMC Geriatr. 2019;19(3):13. https://doi.org/10.1186/s12877-018-1021-y

5. Taylor SF, Coogle CL, Cotter JJ, Welleford EA, Copolillo A. Community-Dwelling Older Adults' Adherence to Environmental Fall Prevention Recommendations. J Appl Gerontol. 2019;38(6):755-74. https://doi.org/10.1177/0733464817723087

6. Mittaz Hager AGM, Mathieu N, Lenoble-Hoskovec C, Swanenburg J, Bie R, Hilfiker R. Effects of three home-based exercise programmes regarding falls, quality of life and exercise-adherence in older adults at risk of falling: protocol for a randomized controlled trial. BMC Geriatr. 2019;19(13). https://doi.org/10.1186/s12877-018-1021-y

7. Hauser E, Gonçalves AK, Martins VF, Blessmann EJ. Motivos de desistência em um programa de atividades física para idosos. Rev Kairós. 2014;17(2):43-56. https://doi.org/10.23925/2176-901X.2014v17i2p43-56

8. Kirchhoff M, Damgaard K. Cognitive and physical resources are important in order to complete a geriatric fall prevention programme. Dan Med J [Internet]. 2016 [cited 2019 Jan 18];63(1):A5175. Available from: https://pubmed.ncbi.nlm.nih.gov/26726903/

9. Hancox JE, van der Wardt V, Pollock K, Booth V, Vedhara K, Harwood RH. Factors influencing adherence to home-based strength and balance exercises among older adults with mild cognitive impairment and early dementia: promoting activity, independence and stability in early dementia (PrAISED). PLoS One. 2019;14(5):e0217387. https://doi.org/10.1371/journal.pone.0217387

10. Sandlund M, Skelton DA, Poh P, Ahlgren C, Melander-Wikman A, Lundin-Olsson L. Gender perspectives on views and preferences of older people on exercise to prevent falls: a systematic mixed studies review. BMC Geriatr. 2017;17:58. https://doi.org/10.1186/s12877-017-0451-2

11. Luzardo AR, Paula Jr NF, Medeiros M, Wolkers PCB, Santos SMA. Repercussões da hospitalização por queda de idosos: cuidado e prevenção em saúde. Rev Bras Enferm. 2018;71(suppl 2). https://doi.org/10.1590/0034-7167-2017-0069

12. Gardiner S, Glogowska M, Stoddart C, Pendlebury S, Lasserson D, Jackson D. Older people's experiences of falling and perceived risk of falls in the community: a narrative synthesis of qualitative research. Int J Older People Nurs. 2017;12(4). https://doi.org/ 10.1111/opn.12151

13. Horne M, Skelton DA, Speed S, Todd C. Falls prevention and the value of exercise: salient beliefs among South Asian and White British older adults. Clin Nurs Res. 2014;23(1):94-110. https://doi.org/10.1177/1054773813488938

14. Jong LD, Francis-Coad J, Wortham C, Haines TP, Skelton DA, Weselman T, et al. Evaluating audio-visual falls prevention messages with community-dwelling older people using a World Café forum approach. BMC Geriatr. 2019;19(345). https://doi.org/10.1186/ s12877-019-1344-3

15. Dolan $\mathrm{H}$, Taylor-Piliae R. Selecting a theoretical framework to guide a research study of older adults' perceptions and experiences of falling in the hospital. Appl Nurs Res. 2019;47:38-40. https://doi.org/10.1016/j.apnr.2019.04.004

16. Maneeprom N, Taneepanichskul S, Panza A, Suputtitada A. Effectiveness of robotics fall prevention program among elderly in senior housings, Bangkok, Thailand: a quasi-experimental study. Clin Interv Aging. 2019;14:335-346. https://doi.org/10.2147/CIA.S182336

17. Stevens JA, Sleet DA, Rubenstein LZ. The influence of older adults' beliefs and attitudes on adopting fall prevention behaviors. Am J Lifestyle Med. 2017;12(4):324-330. https://doi.org/10.1177/1559827616687263

18. Sharafkhani N, Khorsandi M, Shamsi M, Ranjbaran M. The Effect of an Educational Intervention Program on the Adoption of Low Back Pain Preventive Behaviors in Nurses: an application of the health belief model. Global Spine J. 2016;6(1):29-34. https://doi. org/10.1055/s-0035-1555658 
19. Zare M, Ghodsbin F, Jahanbin I, Ariafar A, Keshavarzi S, Izadi T. The effect of health belief model-based education on knowledge and prostate cancer screening behaviors: a randomized controlled trial. IJCBNM [Internet]. 2016 [cited 2017 Feb 12];4(1):57-68. Available from: https://www.ncbi.nlm.nih.gov/pmc/articles/PMC4709816/

20. Zeigheimat F, Ebadi A, Rahmati-Najarkolaei F, Ghadamgahi F. An investigation into the effect of health belief model-based education on healthcare behaviors of nursing staff in controlling nosocomial infections. J Educ Health Promot. 2016;5:23. https://doi. org/10.4103/2277-9531.184549

21. Khorsandi M, Fekrizadeh Z, Roozbahani N. Investigation of the effect of education based on the health belief model on the adoption of hypertension-controlling behaviors in the elderly. Clin Interv Aging. 2017;12:233-240. https://doi.org/10.2147/CIA.S117142

22. Iranagh JA, Rahman HA, Motalebi SA. Health belief model-based intervention to improve nutritional behavior among elderly women. Nutr Res Pract. 2016;10(3):352-8. https://doi.org/10.4162/nrp.2016.10.3.352

23. Carvalho KM, Silva CRDT, Figueiredo MLF, Nogueira LT, Andrade EMLR. Educational interventions for the health promotion of the elderly: integrative review. Acta Paul Enferm. 2018;31(4):446-54. https://doi.org/10.1590/1982-0194201800062

24. Munro S, Lewin S, Swart T, Volmink J. A review of health behaviour theories: how useful are these for developing interventions to promote long-term medication adherence for TB and HIV/AIDS? BMC Public Health. 2007;7(1):104. https://doi.org/10.1186/1471-2458-7-104

25. Glanz K, Bishop DB. The role of behavioral science theory in development and implementation of public health interventions. Annu Rev Public Health. 2010;31:399-418. https://doi.org/10.1146/annurev.publhealth.012809.103604

26. Zhang LL, Dalal K, Yin MM, Yuan DG, Andrews JY, Wang SM. The KAP evaluation of intervention on fall-induced injuries among elders in a safe community in Shanghai, China. PLoS One. 2012;7(3):e32848. https://doi.org/10.1371/journal.pone.0032848

27. Chen SF, Huang SF, Lu LT, Wang MC, Liao JY, Guo JL. Patterns of perspectives on fall-prevention beliefs by community-dwelling older adults: a Q method investigation. BMC Geriatr. 2016;16(132). https://doi.org/10.1186/s12877-016-0307-1

28. Bertolucci PHF, Brucki SMD, Campacci SR, Juliano Y. O Mini-Exame do Estado Mental em uma população geral: impacto da escolaridade. Arq Neuro-Psiquiatr. 1994;52(1):1-7. https://doi.org/10.1590/S0004-282X1994000100001

29. Dela Coleta MF. Crenças sobre comportamentos de saúde e adesão à prevenção e ao controle de doenças cardiovasculares. Mudanças Psicol Saúde. 2010;18(1-2):69-78. https://doi.org/10.15603/2176-1019/mud.v18n1-2p69-78

30. Rosenstock IM. Historical origins of Health Belief Model. Health Educ Behv. 1974;2(4):328-35. https://doi.org/10.1177/109019817400200403

31. Becker MH, Haefner DP, KasI SV, Kirscht JP, Maiman LA, Rosenstock IM. Selected psychosocial models and correlates of individual healthrelated behaviors. Med Care. 1977;15(5 SUPPL):27-46. https://doi:10.1097/00005650-197705001-00005

32. Janz NK, Becker MH. The Health Belief Model: a decade later. Health Educ Q Spring 1984;11(1):1-47. https://doi. org/10.1177/109019818401100101

33. Lescura Y, Mamede MV. Educação em saúde: abordagem para o enfermeiro. São Paulo: Sarvier, 1990.

34. Carvalho NC. Dinâmicas para idosos: 125 jogos e brincadeiras adaptados. 5. ed. Rio de Janeiro: Vozes; 2012.

35. Blaz BS, Azevedo RCS, Agulhó DLZ, Reiners AAO, Segri NJ, Pinheiro TAB. Perception of elderly related to the risk of falls and their associated factors. Esc Anna Nery. 2020;24(1):e20190079. https://doi.org/10.1590/2177-9465-ean-2019-0079

36. Tola HH, Karimi M, Yekaninejad MS. Effects of sociodemographic characteristics and patients' health beliefs on tuberculosis treatment adherence in Ethiopia: a structural equation modelling approach. Infect Dis Poverty. 2017;6(1):167. https://doi.org/10.1186/ s40249-017-0380-5

37. Peikani FA, Shahgholian N, Kazemi A. The Effect of Health-belief-model-Based Training on Behaviors Preventing Peritonitis in Patients on Peritoneal Dialysis. Int J Prev Med. 2018;9:72. https://doi.org/10.4103/ijpvm.IJPVM_566_17

38. Rabelo DF, Neri AL. Intervenções psicossociais com grupos de idosos. Rev Kairós. 2013;16(6),43-63. https://doi. org/10.23925/2176-901X.2013v16i4p43-63

39. Liu H, Shen J, Xiao LD. Effectiveness of an educational intervention on improving knowledge level of Chinese registered nurses on prevention of falls in hospitalized older people: a randomized controlled trial. Nurse Educ Today. 2012;32,695-702. https://doi.org/10.1016/j.nedt.2011.09.009

40. Mendizábal MRL, Cabornero JAC. Grupo de debate para idosos: guia prático para coordenadores dos encontros. São Paulo: Edições Loyola; 2004.

41. Silva RC. Metodologias participativas para trabalhos de promoção de saúde e cidadania. São Paulo: Vetor, 2002.

42. Nicola A, Paniz C. A importância da utilização de diferentes recursos didáticos no Ensino de Ciências e Biologia. InFor [Internet]. 2016 [cited 2019 Jan 18];2(1):355-81. Available from: https://ojs.ead.unesp.br/index.php/nead/article/view/InFor2120167/pdf

43. Polit DF, Beck CT. Fundamentos de pesquisa em enfermagem: avaliação de evidências para a prática da enfermagem. 7. ed. Porto Alegre: Artmed; 2011.

44. Gallardo RY, Alvarado HA, Aguayo ER. La técnica de viñeta y su aplicación en investigaciones en enfermeira. Cienc Enferm. 2012;18(3):9-15. https://doi.org/10.4067/S0717-95532012000300002

45. Evans SC, Roberts MC, Keeley JW, Blossom JB, Amaro CM, Garcia AM, et al. Vignette methodologies for studying clinicians' decisionmaking: validity, utility, and application in ICD-11 field studies. Int J Clin Health Psychol. 2015;15(2):160-170. https://doi.org/10.1016/j. ijchp.2014.12.001 
46. Hughes R, Huby M. The construction and interpretation of vignettes in social research. Soc Work Soc Sci Rev. 2004;11(1):36-5. https://doi. org/10.1921/17466105.11.1.36

47. Carmel S. The Health Belief Model in the research of AIDS-related preventive behavior. Public Health Rev [Internet]. 1990-1991 [cited 2016 Jun 17];18:73-85. Available from: https://pubmed.ncbi.nlm.nih.gov/2132884/

48. Mardegan KJ, Schofield MJ, Murphy GC. Comparison of an interactive CD-based and traditional instructor-led Basic Life Support skills training for nurses. Aust Crit Care. 2015;28(3):160-167. https://doi.org/10.1016/j.aucc.2014.06.001

49. Costa RRO, Medeiros SM, Martins JCA, Menezes RMP, Araújo MS. O uso da simulação no contexto da educação e formação em saúde e enfermagem: uma reflexão acadêmica. Rev Espaço Saúde. 2015;16(1):59-65. https://doi.org/10.22421/1517-7130.2015v16n1p59

50. Diddana TZ, Kelkay GN, Dola AN, Sadore AA. Effect of nutrition education based on health belief model on nutritional knowledge and dietary practice of pregnant women in Dessie Town, Northeast Ethiopia: a cluster randomized control trial. J Nutr Metab 2018;2018:6731815. https://doi.org/10.1155/2018/6731815

51. Estrela KCA, Alves ACC, Gomes TT, Isosaki M. Adherence to nutritional orientations: a literature review. Demetra. 2017;12(1);249-274. https:// doi.org/10.12957/demetra.2017.22407 